\title{
Hydrological and Hydraulic Analyses of Urban Storm Water Drainage System of Major Area of Pokhara, Nepal
}

\author{
Keshav Basnet", ${ }^{*}$, Krishna Chettri ${ }^{1}$, Ganesh Parajuli ${ }^{2}$, and Achyut Bhandari ${ }^{1}$ \\ ${ }^{1}$ Department of Civil and Geomatics Engineering, Pashchimanchal Campus, Institute of Engineering, \\ Tribhuvan University, Pokhara, Nepal \\ ${ }^{2}$ Parajuli Software Pvt. Ltd., Kathmandu, Nepal
}

"Corresponding Email: basnet.keshav@gmail.com

\begin{abstract}
The immense increase of the structural activity which decreases the pervious area of the city is alarming danger situation pertaining to drainage. Urbanization and improved area of imperviousness are the major contributors that make the existing drainage network insufficient while inadequate maintenance and haphazardly throwing rubbish on the road and drain are other issues. The major objective of the study is to analyze the hydrological and hydraulic status of the urban storm water drainage system of the major area of Pokhara City of Nepal and to compare the calculated result with existing situation, using Rehm tools HYKAS and GraPS under AutoCAD environment. The results of this study show that the size of the existing road side drains is inadequate to handle all the surface runoff. It is found that the existing situation of the drainage system is quite poor and need to be redesign or reconstruct immediately. The hydraulic load of almost all the conduit is beyond the limit assigned. The hydraulic design of the most of the drainage conduit is inadequate and re-design of the drain is essential based upon accurate flow estimation methods. This study concludes that the applicability of the current drainage system is quite poor and needs to make certain changes with their construction immediately in order to avoid any danger and adverse effect possessed by surface flooding over the road surface and other paved surfaces. The surface runoff is significantly increased compared to the situation before the construction of existing drainage system and therefore for the appropriate storm water management of the urban area of Nepal, it is critical to design the drainage system based on both hydrological and hydraulic analyses considering reliable data.
\end{abstract}

Keywords: Flooding, HYKAS, Overflow, Rain Side Drain, Storm Water Management

\section{INTRODUCTION}

Pokhara has the record of rapid urbanization and change in huge amount of land use in past decade. Also being the area with highest precipitation rates in the country [1], (3350 mm/year in valley to 5600 $\mathrm{mm} /$ year in Lumle, and the northern hill of the valley), the management of urban storm water in the rainy season seems to be a brain storming and important task for the planners in this sector. Therefore, 
a comprehensive hydrological study must be carried out for the proper management of storm water [2], [3]. The city being in the vicinity of different important watersheds and rapidly developing area, the infrastructures built up in the past and its concession in the present days has been questioned on recent days. To answer the question, the study was done for comparing calculated result with existing infrastructures, redesigning and recommending for the future research works towards the hydrological and hydraulic analysis of the storm drainage network of the valley. The study was performed with a SEWERPAC program named HYKAS, a powerful program for hydraulic calculation of urban sewerage system. Though modeling of storm water drainage is recently started in Nepal, developed countries successfully practicing it using different models (e.g., SWMM; [4]). The output of the study is more beneficial to planners and engineers involved institutions responsible for maintenance and control of drainage system like Department of Road (DoR) and Pokhara Metropolitan City (PMC) for proper allocation of budget too. This study is considered for the storm water alone and major calculation is conducted on the most problematic drainage network of the Pokhara City, Nepal.

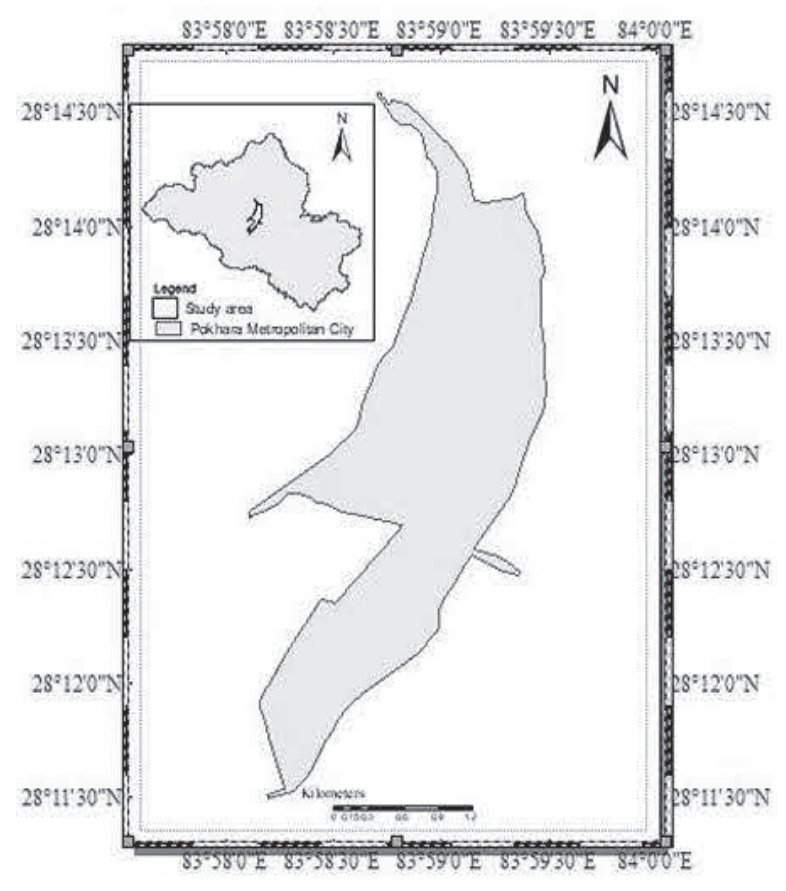

Figure 1 Study Area

\section{MATERIALS AND METHODS}

\subsection{CATCHMENT AREA}

The area is extended from $28^{\circ} 11^{\prime} 30^{\prime \prime} \mathrm{N}, 28^{\circ} 14^{\prime} 30^{\prime \prime} \mathrm{N}$ to $83^{\circ} 58^{\prime} 0^{\prime \prime} \mathrm{E}, 83^{\circ} 58^{\prime} 30^{\prime \prime} \mathrm{E}$. The total area of the study is 4.82 square kilometers. Most of the residential and industrial purposed buildings are equipped with soak pit system therefore no or little amount of grey water is mixed with surface drainage network.

The catchment imperviousness was computed from the information in GIS dataset and land use maps and found to be $29-80 \%$. The land use conditions of these catchments are barren land, agricultural land, roads, residential, industrial, and commercial or a mixture of these. 


\subsection{DATA COLLECTION}

Field observation and measurements made gave the primary data while the data from related articles, papers, thesis, experts, stakeholders, different government authorities such as DoR, PMC, Department of Hydrology and Meteorology (DHM), Kaski, considered as secondary data for the study.

Catchment and hydraulic data were compiled from several sources including drainage, contour, land use and soil maps, aerial photographs, site visits, and drainage design and asset management information.

\subsubsection{RAINFALL DATA}

The rainfall data for the catchment under consideration were gathered from the closest rainfall gauging station placed at Airport Station. The rainfall data of the area was collected from Department of Hydrology and Meteorology, Pokhara, Kaski.

Department of Hydrology and Meteorology analyzed the rainfall intensity records of Pokhara Airport Rainfall Station as according to the automatically recorded data available in internal document of Department of Hydrology and Meteorology and formulated a mathematical empirical equation as follows:

$$
t_{2}=\frac{1510}{\left(t_{c}+11.3\right)^{0.75}} \text { and } t_{5}=\frac{1590}{\left(t_{c}+8.77\right)^{0.75}}
$$

Where,

$\mathrm{t}_{2}=$ Rainfall intensity in $\mathrm{mm} / \mathrm{hr}$ for 2 years of return period,

$\mathrm{t}_{5}=$ Rainfall intensity in $\mathrm{mm} / \mathrm{hr}$ for 5 years of return period,

$\mathrm{t}_{\mathrm{c}}=$ time of concentration in minutes

The rainfall intensity used in this study is taken as $152 \mathrm{~mm} / \mathrm{hr}$ i.e. $423 \mathrm{l} / \mathrm{s}$ *ha for 2 -year return period and 10 minutes of time of concentration taking reference of the same intensity that was used while designing the drainage system in PMC in 1997 under the Pokhara Environmental Improvement Project (PEIP).

\subsubsection{CATCHMENT SYSTEM DATA}

The physical properties of the study catchment and their drainage data were collected which included channel/pipe system and land use layout, catchment areas, percentage pervious and impervious areas, soil types or infiltration characteristics of catchment soil, topography of the catchment, length of overland flow path and dimension and slopes of the catchment. The Google earth image was georeferenced in ArcGIS environment and later those data were used to delineate the catchment along with contour lines. The contour of the concerned area was found from google maps and used for the determination of direction of surface flow and area of sub-catchment.

\subsubsection{DRAINAGE SYSTEM DATA}

The major drainage network of the city was planned, designed and constructed by PMC, former Pokhara sub-metropolitan city, with the financial assistance from Asian Development Bank (ADB) during 1994 AD. At that period, total 25-kilometer length road was furnished with surface drainage network concluding total of 50-kilometer length drain. The existing drainage details were collected from document of PMC, field measurement using measuring tape, GPS and Goggle earth data and presented in Table 1 . 
Table 1: Existing drain dimension and outfall

\begin{tabular}{|c|c|c|c|c|c|}
\hline S.N. & Order & Length(m) & \multicolumn{2}{|c|}{ Dimension } & Outfall \\
\hline & & & Right & Left & \\
\hline 1 & Prithvi Chowk - Seti Bridge & 405 & & $1.6 \mathrm{~m} * 1 \mathrm{~m}$ & Seti River \\
\hline 2 & Savagriha Chowk - Prithvi Chowk & 155 & & $1.2 \mathrm{~m} * 1 \mathrm{~m}$ & Seti River \\
\hline 3 & Savagriha Chowk - Srijana Chowk & 300 & $0.6 \mathrm{~m} * 0.6 \mathrm{~m}$ & $0.6 \mathrm{~m} * 0.6 \mathrm{~m}$ & Fewa Lake \\
\hline 4 & Srijana Chowk - Firke Khola & 395 & $0.6 \mathrm{~m} * 0.8 \mathrm{~m}$ & $0.6 \mathrm{~m} * 0.8 \mathrm{~m}$ & Firke Khola \\
\hline 5 & Zero KM - Firke Khola & 144 & $0.6 \mathrm{~m} * 0.8 \mathrm{~m}$ & $0.6 \mathrm{~m} * 0.8 \mathrm{~m}$ & Firke Khola \\
\hline 6 & Firke bridge - Zero KM & 1853 & $0.6 \mathrm{~m} * 0.95 \mathrm{~m}$ & $0.6 \mathrm{~m} * 0.95 \mathrm{~m}$ & Firke Khola \\
\hline 7 & Bindabasini Chowk - Firke Bridge & 992 & $0.6 \mathrm{~m} * 0.95 \mathrm{~m}, 0.6 \mathrm{~m} * 0.8 \mathrm{~m}$ & $0.6 \mathrm{~m} * 0.95 \mathrm{~m}, 0.6 \mathrm{~m} * 0.8 \mathrm{~m}$ & Firke Khola \\
\hline 8 & Prithvi Chowk - Birauta Canal & 1441.5 & $\begin{array}{c}0.4 \mathrm{~m} * 0.6 \mathrm{~m}, 0.5 \mathrm{~m} * 0.8 \mathrm{~m} \\
0.7 \mathrm{~m} * 1 \mathrm{~m}\end{array}$ & $0.4 \mathrm{~m} * 0.6 \mathrm{~m}, 0.7 \mathrm{~m} * 1 \mathrm{~m}$ & Fewa Canal \\
\hline 9 & Bindabasini-Srijanachowk-Damside & 4987 & $0.4 \mathrm{~m} * 0.5 \mathrm{~m}, 0.5 \mathrm{~m} * 0.6 \mathrm{~m}$ & $0.4 \mathrm{~m} * 0.5 \mathrm{~m}, 0.5 \mathrm{~m} * 0.6 \mathrm{~m}$ & Fewa Lake \\
\hline 10 & Chipledhunga - Savaghriha Chowk & 1524 & $0.5 \mathrm{~m} * 0.6 \mathrm{~m}, 1 \mathrm{~m} * 1 \mathrm{~m}$ & $0.5 \mathrm{~m} * 0.6 \mathrm{~m}, 1 \mathrm{~m} * 1 \mathrm{~m}$ & Seti River \\
\hline 11 & Jalpa Road & 799 & $0.6 \mathrm{~m} * 0.95 \mathrm{~m}$ & $0.6 \mathrm{~m} * 0.95 \mathrm{~m}$ & Fewa Lake \\
\hline 12 & Nadipur - Manipal Chowk Nadipur & 386 & $0.6 \mathrm{~m} * 0.95 \mathrm{~m}$ & $0.6 \mathrm{~m} * 0.95 \mathrm{~m}$ & Seti River \\
\hline 13 & $\begin{array}{l}\text { Manipal Chowk Nadipur- } \\
\text { Mahendapul }\end{array}$ & 761 & $0.6 \mathrm{~m} * 0.95 \mathrm{~m}, 0.7 \mathrm{~m} * 0.6 \mathrm{~m}$ & $\begin{array}{c}0.6 \mathrm{~m}^{*} 0.95 \mathrm{~m}, 0.7 \mathrm{~m} * 0.6 \mathrm{~m} \\
, 0.6 \mathrm{~m} * 1 \mathrm{~m}\end{array}$ & Seti River \\
\hline 14 & Mahedrapul - Nayabazar height & 220.5 & $0.6 \mathrm{~m} * 0.9 \mathrm{~m}$ & $0.6 \mathrm{~m} * 0.9 \mathrm{~m}$ & Seti River \\
\hline 15 & Nayabazar height - Prithvi Chowk & 1354 & $0.4 \mathrm{~m} * 0.4 \mathrm{~m}, 0.5 \mathrm{~m} * 0.7 \mathrm{~m}$ & $0.4 \mathrm{~m} * 0.4 \mathrm{~m}, 0.5 \mathrm{~m} * 0.7 \mathrm{~m}$ & Seti River \\
\hline 16 & Bhairavtole Chowk - Nadipur & 473 & $0.6 \mathrm{~m} * 0.95 \mathrm{~m}$ & $0.6 \mathrm{~m} * 0.95 \mathrm{~m}$ & Seti Canal \\
\hline 17 & Ganeshtole - Palikhe Chowk & 795 & $0.6 \mathrm{~m} * 0.95 \mathrm{~m}$ & $0.6 \mathrm{~m} * 0.95 \mathrm{~m}$ & Seti River \\
\hline 18 & Bindabasini Hall road & 297 & $0.6 \mathrm{~m} * 0.95 \mathrm{~m}$ & $0.6 \mathrm{~m} * 0.95 \mathrm{~m}$ & Seti River \\
\hline 19 & Ghairhapatan road & 615 & $0.6 \mathrm{~m} * 0.95 \mathrm{~m}$ & $0.6 \mathrm{~m} * 0.95 \mathrm{~m}$ & Seti River \\
\hline 20 & Chipledhunga - Mahendrapul & 313.5 & $0.6 \mathrm{~m} * 0.95 \mathrm{~m}$ & $0.6 \mathrm{~m} * 0.95 \mathrm{~m}$ & Seti River \\
\hline 21 & Chipledhunga - Siddhartha Chowk & 291 & $0.6 \mathrm{~m} * 0.95 \mathrm{~m}$ & $0.6 \mathrm{~m} * 0.95 \mathrm{~m}$ & Fewa Lake \\
\hline 22 & Siddhartha Chowk - Firke & 299 & $0.6 \mathrm{~m} * 0.95 \mathrm{~m}$ & $0.6 \mathrm{~m} * 0.95 \mathrm{~m}$ & Firke Khola \\
\hline 23 & Ganesh Road & 797.5 & $0.6 \mathrm{~m} * 0.95 \mathrm{~m}$ & $0.6 \mathrm{~m} * 0.95 \mathrm{~m}$ & Seti River \\
\hline 24 & Zero KM - Bulaudi & 775 & $0.4 \mathrm{~m} * 0.4 \mathrm{~m}$ & $0.4 \mathrm{~m} * 0.4 \mathrm{~m}$ & $\begin{array}{c}\text { Bulaudi } \\
\text { Khola }\end{array}$ \\
\hline 25 & Jalapa Chowk - Nagdhunga & 556 & $0.6 \mathrm{~m} * 0.95 \mathrm{~m}$ & $0.6 \mathrm{~m} * 0.95 \mathrm{~m}$ & Fewa Canal \\
\hline 26 & Ratna Chowk - Airport & 689 & $0.6 \mathrm{~m} * 0.95 \mathrm{~m}$ & $0.6 \mathrm{~m} * 0.95 \mathrm{~m}$ & Fewa Canal \\
\hline 27 & $\begin{array}{l}\text { Mustang Chowk - Rastra Bank } \\
\text { Chowk }\end{array}$ & 488 & $0.6 \mathrm{~m} * 0.95 \mathrm{~m}$ & $0.6 \mathrm{~m}^{*} 0.95 \mathrm{~m}$ & Fewa Canal \\
\hline 28 & Damside - Birauta Chowk & 339.5 & $0.6 \mathrm{~m} * 0.6 \mathrm{~m}$ & $0.6 \mathrm{~m} * 0.6 \mathrm{~m}$ & Fewa Canal \\
\hline
\end{tabular}

\subsubsection{SOIL DATA}

The coefficient of run-off $(\mathrm{C})$ is the portion of precipitation that makes its way to the drain. Its value depends on a large number of factors such as permeability of the surface, type of ground cover, shape and size of catchments area, the topography, and geography, initial state of wetness and duration of storm. The values of runoff coefficient for different kind of surfaces are summarized in Table 2. However, in this study, there are two type of runoff coefficients used: one, 0.55 , for the area with almost $60 \%$ land used as impervious surfaces and the other, 0.90 , for all the asphaltic road surfaces. 
Table 2: Value of Coefficient of Runoff

\begin{tabular}{|c|l|c|}
\hline S.N. & \multicolumn{1}{|c|}{ Description of the Surface } & Coefficient of Runoff \\
\hline 1 & Water tight pavement surface (asphalt or concrete), steep bare rock & 0.90 \\
\hline 2 & Green area (loamy) & 0.30 \\
\hline 3 & Green area (Sandy) & 0.20 \\
\hline 4 & Unpaved area along roads & 0.30 \\
\hline 5 & Lawn and parks & 0.15 \\
\hline 6 & Flat built up area with about 60\% area impervious & 0.55 \\
\hline 7 & Moderately steep built up area with about 55\% area impervious & 0.80 \\
\hline 8 & Most densely built up areas & $0.70-0.90$ \\
\hline 9 & For adjoining area to built up area & $0.50-0.70$ \\
\hline 10 & Residential areas & $0.25-0.50$ \\
\hline 11 & Sub-urban area with few building & $0.10-0.25$ \\
\hline
\end{tabular}

\subsection{HYKAS MODEL}

The program HYKAS (Hydraulische Kanalnetzberechnung System) is used for the hydraulic calculation of urban drainage network according to the latest guideline of DWA (Deutsche Vereinigung für Wasserwirtschaft, Abwasser und Abfall e.V.). In addition to unsteady Hydrodynamic calculation methods, two steady methods, Time Coefficient method and Summation Curve method are also available.

\subsubsection{STEADY METHOD IN HYKAS}

With steady state Flow-Time method (Time-Coefficient and Summation Curve method), an existing network can be computed and partly dimensioned. For dimensioning new sewers, the dimensioning criteria, such as with invert elevation wise, axis wise or crown level wise, were mentioned. Hydraulic calculation within the network is possible simply by changing the properties of the land use attributes.

The basic equation used for hydraulic calculation is,

$$
\frac{V_{u}^{2}}{2 g}+t_{u}+\left(J_{s} \times L\right)=\frac{V_{d}^{2}}{2 g}+t_{d}+\left(J_{e} \times L\right)
$$

Where,

$$
\begin{aligned}
& \mathrm{V}_{\mathrm{u}}=\text { Velocity in upstream section } \\
& \mathrm{V}_{\mathrm{d}}=\text { Velocity in downstream section } \\
& \mathrm{g}=\text { Acceleration due to gravity } \\
& \mathrm{t}_{\mathrm{u}}=\text { Upstream full depth } \\
& \mathrm{t}_{\mathrm{d}}=\text { Downstream full depth } \\
& \mathrm{J}_{\mathrm{S}}=\text { Bed slope } \\
& \mathrm{J}_{\mathrm{e}}=\text { Energy slope } \\
& \mathrm{L}=\text { Pipe length }
\end{aligned}
$$

\subsubsection{RAINFALL INTENSITY METHOD}

In this program, Reinhold formula is used for the calculation of rainfall intensity. The rainfall intensity $r$ $(D, n)$ is calculated as a product of rainfall intensity $r(15,1)$ and the time coefficient $\varphi$, where D is the rainfall duration and $\mathrm{n}$ is the rainfall frequency. 
The reference rainfall intensity value consider in this study according to Reinhold $\mathrm{r}(15,1)$ is $423 \mathrm{l} / \mathrm{s} *$ ha and $10 \mathrm{~min}$ is taken as smallest rainfall duration. The beginning time of reduction method can be selected, so that for the flow time less than the rainfall duration, higher $\varphi$ - values can be used.

$$
\varphi=\frac{38}{T+9} \times\left(\frac{1}{n^{0.25}}-0.369\right)
$$

\subsubsection{INFILTRATION CRITERIA}

Using Time Coefficient method with rainfall intensity according to Reinhold, the seepage flow is implemented as,

$$
Q_{r}=\varphi \times r_{15,1} \times \sum\left(A_{E, N V i} \times \varphi_{i}\right)+\left(\left(\varphi \times r_{15,1} \times \sum A_{E, V i} \times \varphi_{i}\right)-\sum Q_{v i)}\right.
$$

Where,

$$
\begin{aligned}
& A_{E, N V i}=\text { catchment area without infiltration (ha) } \\
& A_{E, V i}=\text { catchment area, with infiltration (ha) } \\
& Q_{V i}=\text { infiltration amount } A_{E, V i} * v i(1 / s) \\
& V_{i}=\text { infiltration capacity }\left(1 / \mathrm{s}^{*} \mathrm{ha}\right) \\
& \varphi=\text { time coefficient } \\
& \psi=\text { Peak runoff coefficient } \\
& r_{15,1}=\text { corresponding rainfall intensity }(1 / \mathrm{s} * \mathrm{ha})
\end{aligned}
$$

For other methods, the infiltration will be considered as,

$$
Q_{r}=r_{D, T} \times \sum\left(A_{E, N V i} \times \varphi_{i}\right)+\left(\left(r_{D, T} \times \sum A_{E, V i} \times \varphi_{i}\right)-\sum Q_{v i}\right)
$$

Where,

$\mathrm{A}_{\mathrm{E}, \mathrm{NVi}}=$ catchment area without infiltration (ha)

$\mathrm{A}_{\mathrm{E}, \mathrm{Vi}}=$ catchment area, with infiltration (ha)

$\mathrm{Q}_{\mathrm{Vi}}=$ infiltration amount $\mathrm{A}_{\mathrm{E}, \mathrm{Vi}}$ * vi (1/s)

$\mathrm{V}_{\mathrm{i}}=$ infiltration capacity $(1 / \mathrm{s} * \mathrm{ha})$

$\psi=$ Peak runoff coefficient

$\mathrm{r}_{\mathrm{D}, \mathrm{T}}=$ rainfall intensity $(\mathrm{l} / \mathrm{s} * \mathrm{ha})$

\subsubsection{DRY WEATHER FLOW}

The dry weather flow QT (1/s) in a conduit is calculated as,

$$
\begin{aligned}
& \mathrm{QT}= \mathrm{A}_{\mathrm{E}, \mathrm{k}} * \mathrm{q}_{\mathrm{H}}+\mathrm{A}_{\mathrm{E}, \mathrm{k}} * \mathrm{q}_{\mathrm{F}}+\mathrm{Q}_{\mathrm{S}, \text { const }}+\mathrm{Q}_{\mathrm{H}, \text { const }}+ \\
& \mathrm{Q}_{\mathrm{T}, \text { const }}+\mathrm{Q}_{\mathrm{G}, \text { const }}+\mathrm{Q}_{\mathrm{I}, \text { const }}+\mathrm{Q}_{\mathrm{F}, \text { const }}+\mathrm{Q}_{\mathrm{GW}, \text { const }}
\end{aligned}
$$

where,

$\mathrm{A}_{\mathrm{E}, \mathrm{k}}=$ Subcatchment area in ha

$\mathrm{q}_{\mathrm{H}}=$ Residential waste water (from Landuse table) in $1 / \mathrm{s} *$ ha

$\mathrm{q}_{\mathrm{F}}=$ Infiltrated water (from Landuse table) in $1 / \mathrm{s} *$ ha

$\mathrm{Q}_{\mathrm{S}, \mathrm{const}}=$ Constant waste water flow in $1 / \mathrm{s}$

$\mathrm{Q}_{\mathrm{H}, \mathrm{const}}=$ Constant residential waste water in $\mathrm{l} / \mathrm{s}$

$\mathrm{Q}_{\mathrm{T}, \mathrm{cons}} \mathrm{t}=$ Constant dry weather flow in $\mathrm{l} / \mathrm{s}$

$\mathrm{Q}_{\mathrm{G}, \text { const }}=$ Constant waste water from commercial area in 1/s

$\mathrm{Q}_{\mathrm{I}, \text { const }}=$ Constant Industrial waste water in 1/s

$\mathrm{Q}_{\mathrm{F}, \text { const }}=$ Constant Infiltration in $\mathrm{l} / \mathrm{s}$

$\mathrm{Q}_{\mathrm{GW}, \text { const }}=$ Constant groundwater inflow in $1 / \mathrm{s}$ 


\subsection{DRAINAGE NETWORK}

After collecting all the essential data such as contour maps of the area, existing dimension of the drain, digital images of the area etc., drainage network of the targeted area was prepared in AutoCAD environment along with powerful tool GraPS developed by Rehm software.

\subsubsection{INPUT DATA}

The data (street name, upstream junction/manhole, downstream junction/manhole, conduit shape, conduit length, material of conduit, existing dimension/size, longitudinal slopes, drainage system, operational coefficient $\left(\mathrm{k}_{\mathrm{b}}\right)$, ground and invert elevation of upstream and downstream, outfall of the system etc.) pertaining to the network was gathered through field visits, with the use of GPS, Google earth environment, registered document of PMC etc.

The shape of almost all the existing conduit under consideration is rectangular and common size is $600 \mathrm{~mm} * 950 \mathrm{~mm}$. There is only one conduit having circular shape and the conduit falls in the network of Firke Bridge - Zero KM. Due to simplicity in construction, the rectangular shaped conduit is found common inside the city.

\subsection{OUTFALL}

The outfall of the drainage system was determined through field visits and available documents from PMC. Through the extensive study of drainage network, it was found that most of the outfall is on unstable water courses such as lake, stream (Khola) and irrigation canal. Major and most problematic drain i.e. Bindabasini Chowk - Srijana Chowk- Dam Side drain was found to be discharged on Fewa Lake.

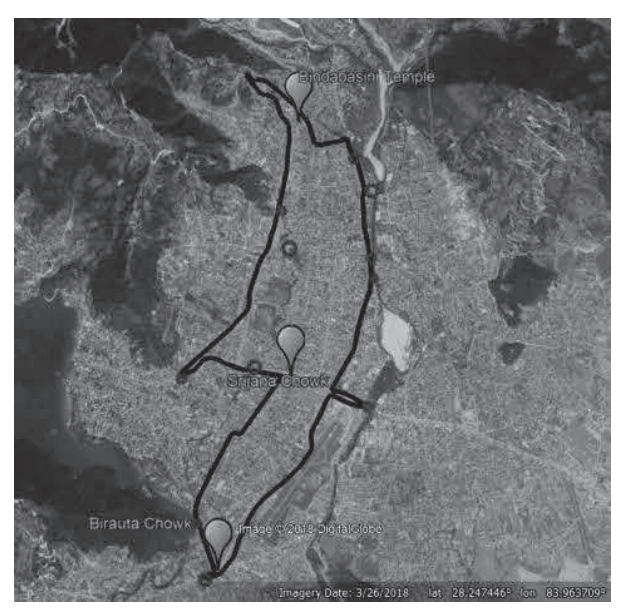

Figure 2 Study Area with Location and Outfall

\section{RESULTS AND DISCUSSIONS}

The study catchment was delineated with the help of contour lines on the GraPS. Individual conduit was given to major and minor sub-catchment from where conduit receives storm water during period of rainfall. The area of catchment was found from created shape file. 


\subsection{LULC MAPS}

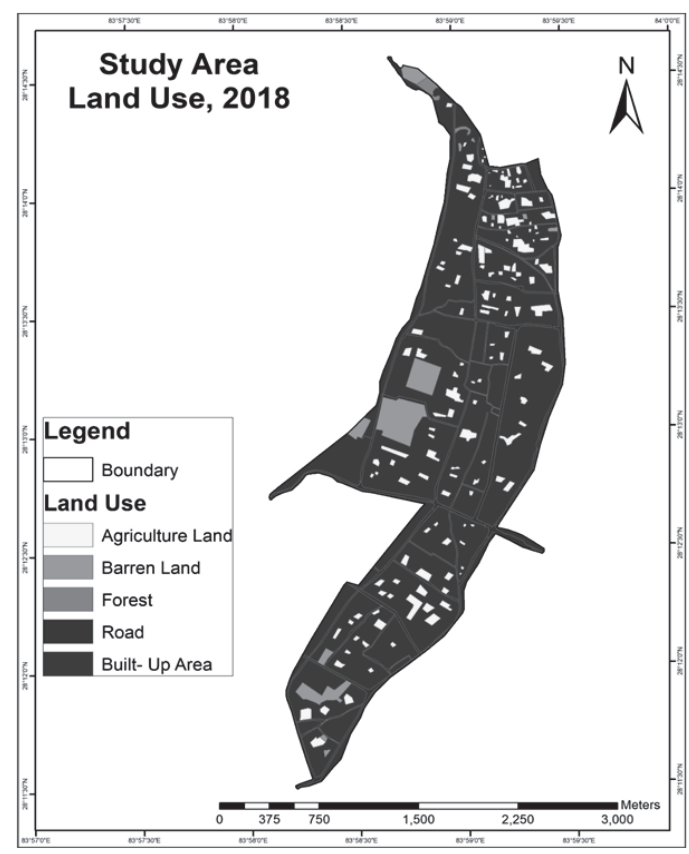

Figure 3: LULC Maps of the Study Area

The land use land cover map (LULC Map) of the concerned area was prepared in the ArcGIS environment with the help of self-digitization of area using goggle imagery as base map followed by generation of shape file.

Table 3: LULC areas

\begin{tabular}{|c|c|c|c|}
\hline S.N. & Land use & Area $\left(\mathbf{m}^{2}\right)$ & Area (\%) \\
\hline 1 & Agricultural land & 338867.66 & 7.03 \\
\hline 2 & Barren land & 228550.20 & 4.74 \\
\hline 3 & Forest & 16378.07 & 0.34 \\
\hline 4 & Road & 393932.38 & 8.17 \\
\hline 5 & Built-up area & 3845122.78 & 79.73 \\
\hline & Total & $\mathbf{4 8 2 2 8 5 1 . 1 0}$ & $\mathbf{1 0 0 . 0 0}$ \\
\hline
\end{tabular}

\subsection{ROAD NETWORK AND STORM WATER DRAIN}

Only few drainage systems are found as open channel drain. Most of the length of road is provided with side drain (top of the drain is covered with RCC slab) i.e. $98 \%$ of the total length of road is constructed along with double side drainage system.

Table 4: Attributes of storm water drain of the considered catchment

\begin{tabular}{|c|c|c|c|}
\hline S.N. & Road & Length of drain(m) & Count \\
\hline 1 & Major road & 10629.00 & 8 \\
\hline 2 & Moderate road & 20063.00 & 9 \\
\hline 3 & Minor road/street & 13457.00 & 11 \\
\hline & Total & $\mathbf{4 4 1 4 9 . 0 0}$ & $\mathbf{2 8}$ \\
\hline
\end{tabular}


The drainage network under those roads were grouped together and assigned in different drainage network as shown in the Table 5. The drainage network in different road was converted into twelve different drainage networks in this study. The details about the different network and their respective length are shown in the table.

Table 5: Different Network and Their Details

\begin{tabular}{|c|c|c|c|c|c|}
\hline $\begin{array}{l}\text { S. } \\
\text { N. }\end{array}$ & $\begin{array}{c}\text { Road } \\
\text { Network }\end{array}$ & Description & $\begin{array}{l}\text { Drainage } \\
\text { Network }\end{array}$ & $\begin{array}{l}\text { Road Length } \\
(\mathrm{m})\end{array}$ & Drain Length (m) \\
\hline \multirow{8}{*}{1} & \multirow{8}{*}{$\begin{array}{l}\text { Major } \\
\text { Road }\end{array}$} & Prithvi Chowk - Seti Bridge & \multirow{3}{*}{ Prithvi Seti } & 405.00 & 523.00 \\
\hline & & Savagriha Chowk - Prithvi Chowk & & 155.00 & 155.00 \\
\hline & & Savagriha Chowk - Srijana Chowk & & 300.00 & 300.00 \\
\hline & & Srijana Chowk - Firke Khola & Srijanachowk Firke & 395.00 & 790.00 \\
\hline & & Zero KM - Firke Khola & Firke Zero & 144.00 & 288.00 \\
\hline & & Firke bridge - Zero KM & Firke Zero & 1853.00 & 3706.00 \\
\hline & & Bindabasini Chowk - Firke bridge & Bindabasini Firke & 992.00 & 1984.00 \\
\hline & & Prithvi Chowk - Birauta canal & Birauta & 1441.50 & 2883.00 \\
\hline \multirow{7}{*}{2} & \multirow{7}{*}{$\begin{array}{l}\text { Moderate } \\
\text { Road }\end{array}$} & $\begin{array}{l}\text { Bindabasini Chowk- Srijana Chowk- } \\
\text { Dam Side }\end{array}$ & Damside & 4987.00 & 9974.00 \\
\hline & & Chipledhunga - Savaghriha Chowk & Prithvi Seti & 1524.00 & 3048.00 \\
\hline & & Jalpa Road & Damside & 799.00 & 1598.00 \\
\hline & & Nadipur - Manipal Chowk Nadipur & Fulbari & 386.00 & 772.00 \\
\hline & & $\begin{array}{l}\text { Manipal Chowk Nadipur - } \\
\text { Mahendapul }\end{array}$ & Mahendrapool & 761.00 & 1522.00 \\
\hline & & Mahedrapul - Nayabazar height & Nayabazar outfall & 220.50 & 441.00 \\
\hline & & Nayabazar height - Prithvichowk & Prithvi Seti & 1354.00 & 2708.00 \\
\hline \multirow{14}{*}{3} & \multirow{13}{*}{$\begin{array}{l}\text { Minor } \\
\mathrm{road} / \text { Street } \\
\mathrm{s}\end{array}$} & Bhairavtole Chowk - Nadipur & Nadipur Canal & 473.00 & 946.00 \\
\hline & & Ganeshtole - Palikhe Chowk & Mahendrapool & 795.00 & 1590.00 \\
\hline & & Bindabasini Hall road & Mahendrapool & 297.00 & 594.00 \\
\hline & & Ghairhapatan road & Mahendrapool & 615.00 & 1230.00 \\
\hline & & Chipledhunga - Mahendrapul & Mahendrapool & 313.50 & 627.00 \\
\hline & & Chipledhunga - Siddhartha Chowk & Damside & 291.00 & 582.00 \\
\hline & & Siddhartha Chowk - Firke & $\begin{array}{l}\text { Siddharathachowk } \\
\text { Firke }\end{array}$ & 299.00 & 598.00 \\
\hline & & Ganesh Road & Prithvi Seti & 797.50 & 1595.00 \\
\hline & & Zero KM - Bulaudi & Zero Bulaudi & 775.00 & 1550.00 \\
\hline & & Jalapa Chowk - Nagdhunga & Birauta & 556.00 & 1112.00 \\
\hline & & Ratna Chowk - Airport & Birauta & 689.00 & 1378.00 \\
\hline & & $\begin{array}{l}\text { Mustang Chowk - Rastra Bank } \\
\text { Chowk }\end{array}$ & Damside & 488.00 & 976.00 \\
\hline & & Dam Side - Birauta Chowk & Birauta & 339.50 & 679.00 \\
\hline & & & Total & 22445.50 & 44149.00 \\
\hline
\end{tabular}

Most of the drains was designed for rain water as load only and function under gravity system. The longest drainage network is Damside network and Fulbari is the least long network under study. 
Table 6: Drainage Network and Total Length

\begin{tabular}{|c|l|l|l|}
\hline S.N. & \multicolumn{1}{|c|}{ Drainage Network } & \multicolumn{1}{c|}{ Total length (m) } & \multicolumn{1}{c|}{ Outfall } \\
\hline 1 & Prithvi Seti & 8329.00 & Seti River \\
\hline 2 & Mahendrapool & 5563.00 & Seti River \\
\hline 3 & Fulbari & 772.00 & Seti River \\
\hline 4 & Nayabazar Outfall & 441.00 & Seti River \\
\hline 5 & Damside & 13130.00 & Fewa Lake \\
\hline 6 & Bindabasini Firke & 1984.00 & Firke River \\
\hline 7 & Firke Zero & 3994.00 & Firke River \\
\hline 8 & Siddharthachowk Firke & 598.00 & Firke River \\
\hline 9 & Srijanachowk Firke & 790.00 & Firke River \\
\hline 10 & Zero Bulaudi & 1550.00 & Bulaudi River \\
\hline 11 & Nadipur Canal & 946.00 & Nadipur Canal \\
\hline 12 & Birauta & 6052.00 & Fewa Canal \\
\hline & Total & $\mathbf{4 4 1 4 9 . 0 0}$ & \\
\hline
\end{tabular}

\subsubsection{DRAINAGE NETWORK: BIRAUTA}

The total length of the network is $2600 \mathrm{~m}$ and all length is equipped with two-sided open rectangular drainage system. The total catchment area which is directly connected to this network is 74.70 ha. More than $70 \%$ of the catchment area is impervious which includes the paved road, residential and commercial buildings, educational institutions, hospitals etc. It was found from the study that the existing drainage system is unable to function properly and the major reason behind it is inadequate capacity of the current drain and improper maintenance.

\subsubsection{DAMSIDE DRAINAGE NETWORK}

It is the longest drainage network considered in the study with the total length of $4987 \mathrm{~m}$. There is only one outfall for the whole length in this network and the water is discharged through Dam Side to the Fewa Lake.

The total catchment area of this network is 126.73 ha and only less than $20 \%$ of which is pervious. Most of the area are covered with residential buildings, footpaths, paved roads etc. The existing size of the rectangular drain provided becomes inadequate due to increased imperviousness than that designed previously. Some of the conduits here have the loading factor of about $550.74 \%$, which clearly states that the existing size of the drain is far below the actual requirement.

\subsubsection{DRAINAGE NETWORK: PRITHVI SETI}

One of the troubles making drainage network which should be redesign in the immediate date to reduce or avoid any harm caused by it is Prithvi Seti. 70.10ha is the total catchment area covered by this network. More than 3/4th of the area is fulfilled with imperviousness thus causing higher percentage of the rainfall to runoff. Paved roads and infrastructural buildings are the main causes of imperviousness in this area.

\subsubsection{DRAINAGE NETWORK: SRIJANACHOWK FIRKE KHOLA}

The load factor of the existing one of the conduits in this area is only $35.22 \%$ which shows that the existing capacity is more than requirement. The designed dimension of the same drain is lower than existing one. This reduced size of the drain not only reduces the construction cost but also saves the costly land. The total catchment area for this conduit is only 1.38 ha. This drain receives rain water from 
the road surfaces mostly and some part of the buildings nears to the drain also has contribution towards this conduit.

\subsubsection{DRAINAGE NETWORK: FIRKE ZERO}

Covering total area of 10.52 ha, this network found out that the sizing of the most of existing conduit is sufficient in capacity to handle available water except two conduits. These two conduits of this network are recently constructed by DoR Pokhara and under study it is found that the water carrying capacity of the drain is quite feasible. The conduit provided received surface water from asphaltic road and area directly connected to it.

\subsection{SIMULATION OF HYKAS MODEL}

HYKAS is powerful tool available which can be used for the analysis, assessment and design of sewer network of any area, especially applicable to urban and sub-urban with or without sewerage system.

\subsubsection{GRADE OF HYDRAULIC LOAD}

The term "Load Factor" is used in this study in order to represent the condition of hydraulic load for different considered conduit. The assigned degree of utilization of dimensioning is limited to $90 \%$.

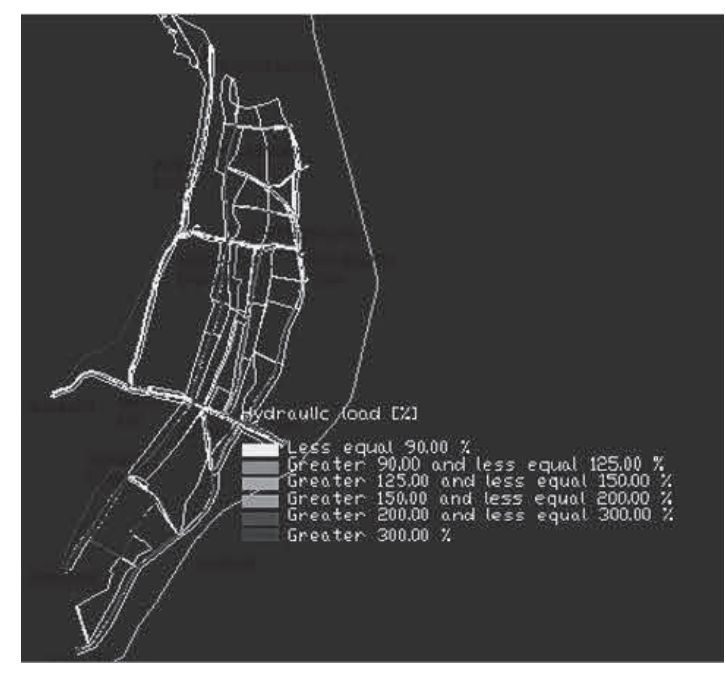

Figure 4: Grade of Hydraulic Load of the Drainage Conduit in Existing Condition

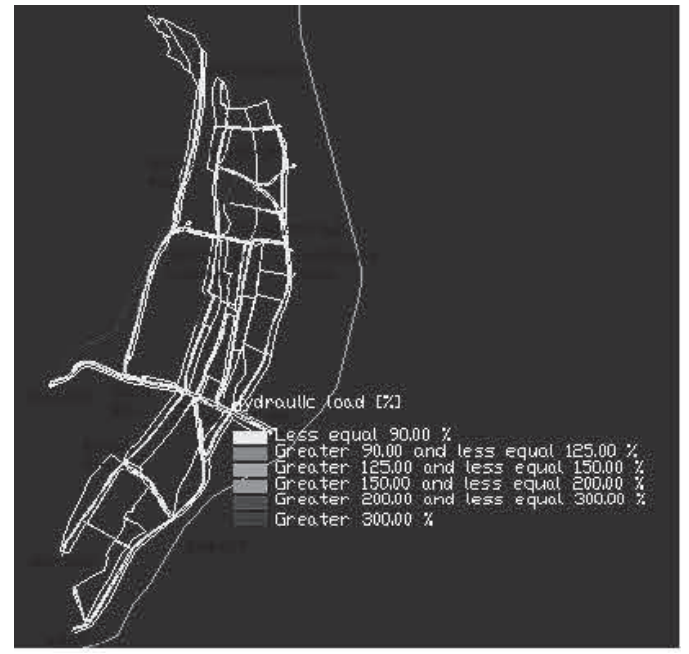

Figure 5 grade of hydraulic load of the drainage conduit in planned condition 


\subsubsection{DRY WEATHER FLOW VELOCITY}

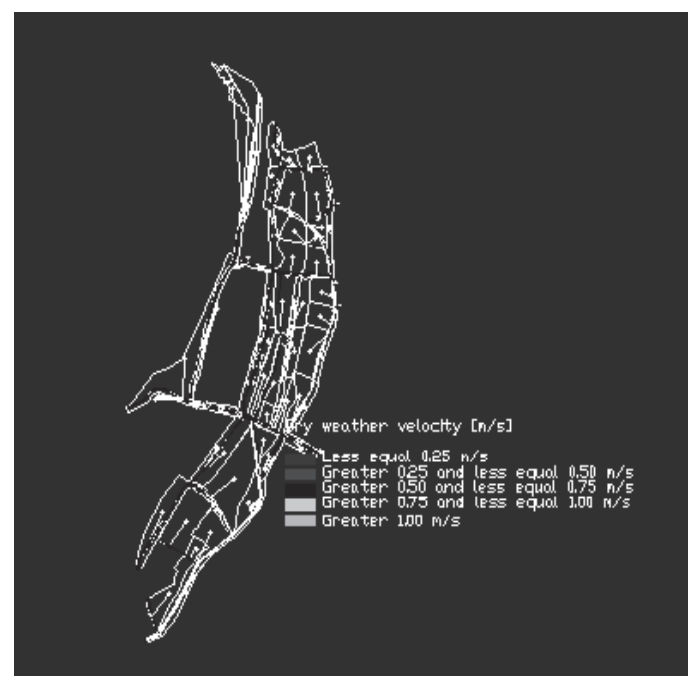

Figure 6: Dry Weather Flow Velocity of the Considered Drainage

In case of dry weather, the flow pattern of the entire drainage network considered does not show any serious sign.

From Figure 6, it can be seen that if the value of DWF is less than or equal to $0.25 \mathrm{n} / \mathrm{s}$ then condition is worse but it will be below normal if the value is above 1 .

\subsubsection{ROUGHNESS COEFFICIENT}

According to the guideline of A110 Chapter (3.1.1), for the determination of full flow values, the operational roughness coefficient $\mathrm{K}_{\mathrm{b}}$ is used. An average $\mathrm{K}_{\mathrm{b}}$ value can be taken as according to the section 4.1.2 and Table 4 of A110 guideline. For the unsteady calculation, instead of general roughness, as according to A110 Ch. 4.4, individual concept can be used for the performance verification of wastewater network.

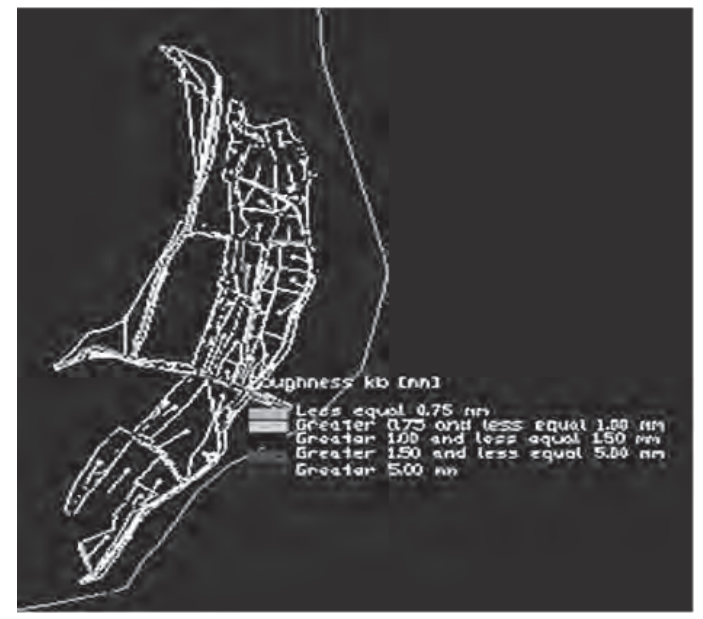

Figure 7: Roughness coefficient 


\subsubsection{OUTFALL OF THE NETWORK}

There are altogether 10 outfall systems in the catchment but only $40 \%$ of this falls in to the Seti River. The quality and beauty of the lake is degrading day to day due to the enrollment of the drainage water along with various kinds of rubbish mixed with them.

\section{CONCLUSION AND RECOMMENDATION}

The problem of the catchment pertaining to flooding during storm events is high due to insufficient drainage provisions and inadequate maintenance adopted. The percentage of the impervious areas is increasing day by day and this ultimately causing the problem of flooding due to creation of high runoff on the surface of the road. The magnitude of surface runoff becomes extremely large in these days due to increased imperviousness. The other conclusions drawn after completion of the study are:

- The hydraulic design of the existing drainage network is inadequate to handle received surface water.

- Re-design and re-construction of existing drainage network is most essential based on the accurate and most reliable flow estimation methods.

- The existing situation of the drainage network is quite complicated to transfer hydraulic load due to long distance. In Dam Side network, the conduit transfers water up to $4987 \mathrm{~m}$.

- More than $80 \%$ of the total considered catchment area is impervious and imperviousness is mainly due to paved road, residential and commercial buildings etc.

- More than $40 \%$ outfall of the drainage network considered in the study is on the unstable water courses.

After getting conclusion of the study, authors recommend for the improvement of the existing drainage situation of the catchment, especially on those areas which is more vulnerable and imposing heavy risk to users. The authors strongly suggest to all the stakeholders and responsible authorities that, it is advisable to construct the drain only after going through extensive ground studies and adopting hydrological design criteria. The maintenance of the drain has also plays the immense role for the effective functioning of the drain. The other recommendations of the study are as following:

- Strong recommendation to government bodies involved in this field (PMC and DoR) that the design and upgradation of the drainage network should be done on the basis of accurate and appropriate hydrological and hydraulic analysis of the particular area. Adequate guidelines should be made considering extensive ground study.

- The design of the perfect functioning of the drain is based on the assessment of the most accurate surface flow which requires the time series rainfall data starting from 1-5 minutes and rainfall pattern during period of rainfall. The drainage design is accurate following unsteady flow an estimation method which requires multiple time series rainfall data; therefore, it is recommended that the government should make the data collection and database system of rainfall.

- The government should prepare the guidelines for accessing the surface runoff for gauged and ungauged catchment separately. Site specific and case-oriented methods should be on the priority in order to access the accurate flows over the road surfaces.

- The change in land use pattern of the area since last few decades and their effects on the surface runoff can be a research topic for future research.

- The effect of grey water on the surface drainage system and receiving water bodies should be considered in the study. The quality of water plays the important role on human and other living thing's health.

- It is recommended to make the trough study considering waste water as load or combined system because in this study, only rain water is taken as load. 
- Storm water management of the city should be the priority of the stakeholder involved in the transportation and environmental field.

\section{ACKNOWLEDGMENT}

Authors want to exceed a gratitude to Ram Chandra Paudel and Daya Sagar Subedi for supporting this study with ArcGIS to complete the research work. Similarly, a thankful note is expressed to all the faculties of MSIEM program at Pashchimanchal Campus who shares their valuable knowledge and nice learning experience. The authors are also thankful to the Department of Hydrology and Meteorology, Kaski, Nepal for providing the daily rainfall data. Most importantly, the authors are thankful to Parajuli Software Pvt. Ltd., Nepal for providing HYKAS software to carry out the present study.

\section{REFERENCES}

[1] S. Rai, "Study on Status of Drainage on Strategic Urban Road under Division Road Office Pokhara", Pokhara University, Pokhara, Nepal, 2015.

[2] K. Basnet, U. Baniya and S. Karki, "Comparative study of design discharge calculation approaches: a case study on Padhu Khola, Kaski, Nepal”, Oodbodhan: A Journal of TUTA, Pashchimanchal Campus, 5 (5), 2018.

[3] K. Basnet and M. Neupane, "Storm water drainage design based on hydrological analysis: a case study on Lamachaur catchment area, Pokhara, Nepal", Oodbodhan: A Journal of TUTA, Pashchimanchal Campus, 5 (5), 2018.

[4] S. Khadka and K. Basnet, "Storm Water Management of Barahi Chowk Area, Lakeside, Pokhara, Nepal using SWMM", 2 ${ }^{\text {nd }}$ International Conference on Engineering \& Technology, 2 (1), 320-325, 2019.

[5] B.K. Mishra, "Impact of Land Use Changes on Runoff Using Remote Sensing and ArcGIS", MSc Thesis, IOE, Pulchowk Campus, Nepal, 2005.

[6] "Brochure of PMC", Pokhara Metropolitan City, Newroad, Pokhara, Nepal, 2013.

[7] S. Sharma, "Impact Study of Imperviousness in Peak Discharges and Land Use Change in Urbanizing Basin", MSc. Thesis, IOE, Pulchowk Campus, Nepal, 2005.

[8] S.T. Dayaratne, "Modelling of Urban Storm Water Drainage System Using ILSAX ", PhD Thesis, Victoria University of Technology, Australia, 2000.

[9] "Designing Safer Side Drain", Department of Road, Design and Planning Branch, Kathmandu, Nepal, 1996.

[10] "Nepal Road Standard”, Department of Road, Planning and Design Branch, Babarmahal, Kathmandu, Nepal, 2013.

[11]G. O'Loughlin and A.G. Goyen, "Computer Models for Urban Storm Water Drainage in Australia", Urban Planning and Storm Water Management Proceedings, Kula Lumper, May 28June 1, 1990.

[12]"Guidelines on Urban Drainage", IRC: SP: 50-1999, Delhi, 1999. 